\title{
Effect of Methods of Adding Vitamin C on Growth Performance and Feed Utilization and Survival of Fingerlings of Nile Tilapia Reared in Happa
}

\author{
Eid, A. E.; Badiaa A. Ali; K. A. Elsayed and M. Elsoady \\ Department of Animal and Fish resources Faculty of Agriculture - Suez Canal University - Ismailia - Egypt
}

Received: $7 / 6 / 2020$

\begin{abstract}
A 56-days growth trial was conducted in happaunder greenhouse culture system to examine the effects of different added vitamin $\mathrm{C}$ on growth, feed utilization and survival rate of Nile tilapia (Oreochrmis niloticus) fingerlings with average initial weight of $8.12 \pm 0.02$ g. Five treatments T1 control added dry vitamin C, T2 mix Vitamin C with water, T3 mix vitamin $\mathrm{C}$ with oil, T4 spry added vitamin with water and T5 spry added vitamin $\mathrm{C}$ with oil. The levels of vitamin $\mathrm{C}(70 \mathrm{mg} / \mathrm{kg})$ and their combination were used to prepare diets used in nine experimental treatments with three replicates. Based on the results of this study, it can be conclude that addition of vitamin $\mathrm{C}$ with oil spry added was the best in terms of growth performance, feed utilization and survival rate.
\end{abstract}

Keywords: Growth performance, feed utilization, adds vitamin C, Nile Tilapia fingerlings

\section{INTRODUCTION}

Vitamin C (ascorbic acid) is an essential nutrient in aqua-feeds, and is an indispensable nutrient required to maintain physiological processes such as normal growth, immunity and reproduction of different animals including fishes (Teshima et al., 1991). Ascorbic acid is water soluble and is essential for several metabolic functions including the antioxidant system. Most fish, including tilapia, are not capable of vitamin C biosynthesis (Chatterjee, 1973) due to the absence of the enzyme Lgulonolactone oxidase, which is responsible for synthesis of ascorbic acid (Wilson, 1973). Lascorbic acid is extremely labile and the rate of degradation is a function of storage time, with the effect of temperature, oxygen, $\mathrm{pH}$ and light. Recent studies indicate that ascorbic acid derivatives that include sulfate and phosphates are more resistant to oxidation and retain ascorbic acid activity for fish (Abdelghany, 1996). Ascorbic acid requirements of some tilapia species have been investigated Stickney et al. (1984), reported the fortification of $50 \mathrm{mg}$ of ascorbic acid equivalent $\mathrm{kg}-1$ diet as the level that allows for maximum weight gain and absence of deficiency signs in blue tilapia (Oreochromis aureus). However, it should be noted that this apparent interaction between method of adding and ascorbic acid stability. However, there is still a paucity of information on the interaction between method of adding vitamin $\mathrm{C}$ and stability. The objective of the present study was to assess the effects of different adding method on growth performance, feed utilization and survival of Nile tilapia fingerlings.

\section{MATERIALS AND METHODS}

The experiment was represented at Al-Amal private fish farm, El Kantara, Ismailia- Egypt. The experiment aim to study the Effect of different method of added Vitamins $\mathrm{C}$ to diets of Nile Tilapia fingerlings.

\section{Water quality parameters}

Were monitored during the study to follow water temperature and dissolved oxygen were measured by mettle Toledo, model 128.s/No1242. Other water quality including $\mathrm{pH}$ and ammonia were measured every two days by $\mathrm{pH}$ meter (Orion model 720A, s/no 13062) and ammonia meter by Hanna ammonia meter. The averages of water quality parameters are presented in Table (1).

Table (1): Water quality parameters

\begin{tabular}{lcccc}
\hline Experimental & Temperature & Dissolved Oxygen & Ammonia & pH \\
\hline Parameters & $28-25$ & $5.7-7 \mathrm{mg} / 1$ & $0.07-0.04 \mathrm{mg} / 1$ & $7.7-9$ \\
\hline
\end{tabular}

\section{Experimental unit}

Fish were stocked in 15 hapa $(1.5 \mathrm{~m} \mathrm{x} 1.00 \mathrm{~m} \mathrm{x}$ 1. m) randomly divided into to equal experimental groups (250 fingerlings/three replicate hapas). The hapa were supplied all day with air blowers. Water temperature was maintained at $\left(25-28^{\circ} \mathrm{C}\right)$ inside green house.

\section{Experimental fish and Culture techniques}

Two thousand and two hundred fifty fingerlings were obtained from Nile tilapia $(O$. niloticus) with an average initial body weight of $8 \pm$
0.1 gm from (Al Amal Fish Farm, Kantara, Ismailia) Governorate, Egypt. Fish were homogeneous in body weights and seemed to be healthy. Prior to the start of the experiment, fish was acclimatized to laboratory conditions for two weeks.

\section{Experimental diets}

The diets were formulated from practical ingredients (Table 2). The experimental diets were formulated to contain almost $30 \%$ crude protein and gross energy $452.84 \mathrm{Kcal} / 100 \mathrm{~g}$. The experimental diets were prepared by individually weighing of each 
component thoroughly mixing the mineral, vitamins and additives with corn. This mixture was added to the components together with oil. Water was added until the mixture became suitable for making granules. The wet mixture was passed through CBM granule machine with powders. The methods used to add vitamins in the diet are as follows;

- Adddry (Control) T1

- Adding with water (T2)

-Adding with mix oil (T3)
- Adding with spray water (T4)

- Adding with spry oil (T5)

The produced diets were dried at room temperature then kept until experimental start. The composition and proximate analysis of the experimental diets are presented in Table (2). The fish were hand-fed to satiation 4 times /day $(7,10,2$, and $4 \mathrm{pm}$ ) throughout the experimental period 56 days.

Table (2): Formulation and chemical composition of the basal diet

\begin{tabular}{ll}
\hline Ingredients & $30 \%$ \\
\hline Fish meal (60\%) & 5 \\
Soya bean meal & 50 \\
Yellow corn & 17 \\
rice bran & 18 \\
Soya oil & 6 \\
Vit. and Min. premix $\mathbf{1}_{\text {free vitamin C }}$ & 3 \\
CMC (carboxy methyl cellulose) & 1 \\
Proximate Analysis & \\
Dry matter (\%) & 87.8 \\
Protein (\%) & 30.08 \\
Lipid \% & 10.49 \\
Total carbohydrate (\%) & 44.71 \\
Ash \% & 5.69 \\
vitamin C mg/kg & 70 \\
Gross energy (Kcal /100g) & 452.84 \\
\hline
\end{tabular}

1. Each Kg vitamin \& mineral mixture premix contained Vitamin D3, 0.8 million IU; A, 4.8 million IU; E, 4 g; K, 0.8 g; B1, 0.4 g; Riboflavin, 1.6 g; B6, 0.6 g, B12, 4 mg; Pantothenic acid, 4 g; Nicotinic acid, 8 g; Folic acid, 0.4 g Biotin, 20 mg , Mn, 22 g; Zn, 22 $\mathrm{g} ; \mathrm{Fe}, 12 \mathrm{~g}$; $\mathrm{Cu}, 4 \mathrm{~g}$; I, $0.4 \mathrm{~g}$, Selenium, $0.4 \mathrm{~g}$ and $\mathrm{Co}, 4.8 \mathrm{mg}$,

2. Gross Energy based on protein $(5.65 \mathrm{Kcal} / \mathrm{g})$, fat $(9.45 \mathrm{Kcal} / \mathrm{g})$ and carbohydrate $(4.11 \mathrm{Kcal} / \mathrm{g})$. According to (NRC, 1993).

\section{Experimental Methodology}

Fish Samples

At the start and the end of the main experimental period (56 day), 5 fish were randomly taken from each experimental group. Fish were used for chemical analysis of the whole body. The tested diets and body were analyzed for crud protein (CP \%) ether extract (EE \%), crude fiber (CF \%), ash (\%) and moisture. The whole body composition of fish samples were analyzed except crud fiber (CF \%) according to the procedures described by standard (AOAC, 2012). The nitrogen free-extract (NFE \%) was calculated by differences.

\section{Growth performance parameters}

The growth performance and feed utilization parameters are calculated according to the follow.

Average Weight Gain (AWG)

$(\mathrm{AWG})=$ Average final weight $(\mathrm{g})-$ Average initial weight $(\mathrm{g})$

Average Daily Gain (ADG): -

$(\mathrm{ADG})=[$ Average final weight $(\mathrm{g})-$ Average initial weight (g)] / time (days)

Specific Growth Rate (SGR \%/day): -

$(\mathrm{SGR} \% /$ day $)=100[$ Ln Wt1 - Ln Wt. $0 /$ t]

Where: - Ln: normal log Wt. 0: initial weight (g).

\section{Wt. 1: final weight $(\mathrm{g}) \quad \mathrm{T}$ : time of days.}

\section{Feed and protein utilization parameters}

Feed and protein utilization parameters are calculated according to the following equations:-

\section{Conversion Ratio (FCR):-}

$\mathrm{FCR}=$ Total feed consumption/ weight gain .

Feed Efficiency $(\mathrm{FE})=$ weight gain/ Total feed consumption

Protein Efficiency Ratio $(\mathbf{P E R})=$ weight gain/protein consumed

\section{Survival (\%):}

$\mathrm{SR}=\mathrm{Ni} \times 100 / \mathrm{N} 0$

Where: $\mathrm{Nt}=$ Total number of fish survived in tank at end of experiment.

No $=$ Total number of fish survived in tank at beginning of experiment.

We analyzed the nutritional parameters of weight gain (WG), apparent feed intake (AFI), apparent feed conversion (AFC), carcass quality and yield (CY), according Equation 1: (1) where: $\mathrm{DCW}=$ dressed carcass weight. We also calculated the Viscerosomatic index (VSI), Gonadosomatic Index (GSI) and Hepatosomatic index (HSI), according Equations: 
$\mathrm{GSI}=\mathrm{GW} / \mathrm{BWX} 100$

$\mathrm{VSI}=$ Viscera weight $/ \mathrm{BWX} 100$

HIS $=$ Liver Weight/BwX100

Carcass Yield $=$ dressed carcass weight

Gonad weight $=$ weight of gonad

\section{Statistical analysis}

The data obtained in this study were analyzed by one-way ANOVA procedure of Statistical Analysis System (SAS Institute, 2005). Means were compared by Duncan's new multiple ranges test (Duncan, 1955).

Where: $Y i j=\mu+D i+e i j$

Yij $=$ The observation of the $\mathrm{j}$ th individual from $\mathrm{D}$ th Diet.

$\mu=$ the overall mean. $\quad \mathrm{Di}=$ The Fixed effect of the D th Diet.

$\mathrm{eij}=$ The random error associated with the individual $\mathrm{j}$.

\section{RESULTS AND DISCUSSION}

\section{Effect of vitamin $C$ on growth}

The effect of different adding vitamin $\mathrm{C}$ on growth performance of Nile tilapia fingerlings are presented in Table 3. The group of fish on T5 had a significantly $(\mathrm{P}<0.05)$ highest final body weight gain, weight gain percent and specific growth rate than the rest of other experimental treatment. The results of this study strongly indicate that different adding vitamin C significantly affects the growth, survival of Nile tilapia fingerlings. Growth is a function of both the nutritional quality and the rate of consumption, among other things (Stickney, 2000). These outcomes suggested that dietary vitamin $\mathrm{C}$ could improve the growth performance of tilapia fingerlings. The results of the present investigation are contrary to some past studies for different fish species (Ai et al., 2004; Lin and Shiau, 2005). Nevertheless, Ai et al. (2006) stated that adding dietary vitamin $\mathrm{C}$ effect levels which didn't affect the growth parameters for juvenile large yellow croaker. There was stunted growthand haemorrhage in head of Japanese eels were observed when fed a vitamin Cdeficient diet (Arai et al., 1972). The reasons for this may be difference in individual size, development stage, cultivation environment, variation in experimental conditions including levels of nutrients interaction in the treatment diets, other feed contents like other vitamins, for example vitamin $\mathrm{E}$ and the response

The group of fish on T5 had a significantly $(\mathrm{P}<0.05)$ highest survival rate $98 \%$ than the rest of experimental groups. The lowest survival was reported around $90 \%$ in $\mathrm{T} 1$ which similar to reported by (Soliman et al., 1986) in tilapia O. mossambicus fed a diet without supplemental ascorbic acid in 8 weeks. These results contradict Falcon et al. (2007), which stated that ascorbic acid directly influences the growth of fish.

\section{Feed Utilization}

The effect of different adding vitamin $\mathrm{C}$ on feed utilization of Nile tilapia fingerlings are presented in Table 4 . The group of fish on T5 had a significantly $(\mathrm{P}<0.05)$ lowest feed intake than the rest of experimental group. The group of fish on T1had a significantly $(\mathrm{P}<0.05)$ highest feed intake than the rest of experimental groups. The group of fish on T5 had a significantly $(\mathrm{P}<0.05)$ lowest feed conversion ratio than the rest of experimental group. And the group on T1 had the highest FCR than the rest of experimental groups. The results of this study strongly indicate that different adding vitamin C significantly affects the growth, survival and hematology of Nile tilapia fingerlings. Feed utilization in this study was also affected by the dietary treatment of ascorbic acid adding Table 4. Total amount of feed consumed increased with ascorbic acid level. Both protein conversion efficiency and protein efficiency ratio were much lower in fish fed with diet without ascorbic acid. This indicates lower protein utilization by the fish. Fracalossi et al. (2001) observed a similar trend in juvenile Oscars (Astronotus ocellatus) cichlids. The diet used in the present experiment had high protein content (400 g kg-1), which could have resulted in the fish consuming high levels of oxygen as consumption increases with protein in tilapia (Ross, 2000). The group of fish fed on T5 had a significantly $(\mathrm{P}<0.05)$ highest Feed efficiency and Protein efficiency ratio. In agreement with Fracalossi et al. (2001). The relationship between spry added vitamin $\mathrm{C}$ with oil T5 showed a significant $(\mathrm{P}<0.05)$ effect on the feed efficiency reaches the highest efficiency.

Table (3): Final weight (FW), total length (TL), standard length (SL), apparent feed intake (AFI), weight gain (WG) and apparent feed conversion (AFC) of Nile tilapia fingerlings fed with diets containing different levels of supplemental vitamin

\begin{tabular}{|c|c|c|c|c|c|}
\hline \multirow{2}{*}{ Item } & \multicolumn{5}{|c|}{ treatment } \\
\hline & T1 & T2 & T3 & T4 & T5 \\
\hline Initial weight (g) & $8.00 \pm 0.10$ & $8.00 \pm 0.10$ & $8.00 \pm 0.10$ & $8.0 \pm 0.10$ & $8.10 \pm 0.10$ \\
\hline Final Weight (g) & $20.22 \pm 0.30^{\mathrm{e}}$ & $21.00 \pm 0.30^{\mathrm{d}}$ & $22.22 \pm .30^{\mathrm{c}}$ & $23.22 \pm 0.30^{\mathrm{b}}$ & $24.22 \pm 0.30^{\mathrm{a}}$ \\
\hline Weight gain (g) & $12.22 \pm 0.20 \mathrm{e}$ & $13.0 \pm 0.20 \mathrm{~d}$ & $14.22 \pm .10 \mathrm{c}$ & $15.22 \pm .20 \mathrm{~b}$ & $16.12 \pm 0.10 \mathrm{a}$ \\
\hline Weight gain \% & $152.75 \pm 0.10 \mathrm{e}$ & $162.5 \pm 0.12 \mathrm{~d}$ & $177.75 \pm .14 \mathrm{c}$ & $190.25 \pm 14 b$ & $199.01 \pm 0.14 \mathrm{a}$ \\
\hline SGR & $1.65 \pm 0.10 \mathrm{e}$ & $1.72 \pm 0.10 \mathrm{~d}$ & $1.82 \pm 0.10$ & $1.90 \pm 0.10 \mathrm{~b}$ & $1.95 \pm 0.10 \mathrm{a}$ \\
\hline Survival \% & $90.00 \pm 0.30^{\mathrm{b}}$ & $95.00 \pm 0.30^{\mathrm{a}}$ & $97.00 \pm 0.30^{\mathrm{a}}$ & $97.00 \pm 0.30^{\mathrm{a}}$ & $98.00 \pm 0.30^{\mathrm{a}}$ \\
\hline
\end{tabular}


Different letters in the row indicate significant differences $(p<0.05)$ by Duncan's test; Mean \pm standard error. There was a significant difference $(\mathrm{P}<0.05)$ between experimental groups (Table 5) in HSI values. The group of Nile tilapia fingerlings on T5 had the highest HIS and the group on T1 had the lowest value of HIS. In agreement with Furuita et al. (2009). There was a significant difference in GSI values between the treatments, with higher values for the treatments T5 and lowest on T1.Similar results was obtained by (Navarro et al., 2009). There was a significant difference $(\mathrm{P}<0.05)$ between experimental groups (Table 4) in GSI values in this way, other studies registered a positive effect on fish reproduction. In agreement with Navarro et al. (2009). There was a significant difference $(\mathrm{P}<0.05)$ between experimental groups (Table 5) in $\mathrm{GW}$ values among experimental groups. In agreement with Soliman et al. (1986). There was a significant difference $(\mathrm{P}<0.05)$ between experimental groups (Table ) in GW. The highest GW was recorded in T5, T4, and T3 and the lowest value of GW in T1, In agreement with Martins et al. (2016).

There was a significant difference $(\mathrm{P}<0.05)$ in carcass yield (CY) among experimental groups. In agreement with Martins et al. (2016).

Table (4): Effect of adding methods of vitamin $\mathrm{C}$ on Feed utilization of Nile tilapia fingerling

\begin{tabular}{|c|c|c|c|c|c|}
\hline \multirow{2}{*}{ Item } & \multicolumn{5}{|c|}{ Treatment } \\
\hline & T1 & $\mathrm{T2}$ & T3 & T4 & T5 \\
\hline Feed intake (g) & $26.88 \pm .20^{\mathrm{b}}$ & $21.58 \pm 0.20^{\mathrm{e}}$ & $29.01 \pm 0.20^{\mathrm{a}}$ & $25.87 \pm 0.20 \mathrm{c}$ & $22.75 \pm 0.20^{\mathrm{d}}$ \\
\hline FCR & $2.2 \pm 0.20^{\mathrm{a}}$ & $1.66 \pm 0.20^{\mathrm{b}}$ & $1.80 \pm 0.10^{\mathrm{d}}$ & $1.70 \pm 0.20^{\mathrm{c}}$ & $1.60 \pm 0.20^{\mathrm{b}}$ \\
\hline $\mathbf{F E}$ & $0.45 \pm 0.10^{\mathrm{e}}$ & $0.60 \pm 0.10^{\mathrm{b}}$ & $0.55 \pm 0.10^{\mathrm{c}}$ & $0.58 \pm 0.20^{\mathrm{e}}$ & $0.62 \pm 0.20^{\mathrm{a}}$ \\
\hline PER & $1.52 \pm 0.20^{\mathrm{e}}$ & $2.00 \pm 0.20^{\mathrm{b}}$ & $1.85 \pm 0.20^{\mathrm{d}}$ & $1.96 \pm 0.20^{\mathrm{c}}$ & $2.09 \pm 0.20^{\mathrm{a}}$ \\
\hline
\end{tabular}

Different letters in the row indicate significant differences $(\mathrm{p}<0.05)$ by Duncan's test; Mean \pm standard error.

The $60 \mathrm{mg}$ ascorbic acid $\mathrm{kg}-1$ diet found as requirement level for maximum growth agrees with $\mathrm{Li}$ and Lovell (1985) who demonstrated that fish rose from 3 to $19 \mathrm{~g}$ required $60 \mathrm{mg}$ ascorbic acid $\mathrm{kg}-1$ diet for maximum weight gain. Weight gain increase with dietary level is considered by many nutritionists to be the most important and meaningful response in nutritional requirement studies (Stickney, 2009). Body proximate composition did not affect with adding methods of vitamin $\mathrm{C}$.

No significant difference was found for viscerossomatic index, hepatosomatic index and gonad weight. The results of chemical analysis of the carcass (dry matter, protein, ether extract) and carcass yield showed no significant difference (Table 5). Probably, the amount and period of experiment were not enough to stimulate collagen synthesis. There was a significant difference $(\mathrm{P}<0.05)$ in GSI values between the treatments, with higher values for the treatments T5. This result demonstrates the importance of the spry adding vitamin C to diets (Navarro et al., 2009).

Table (5): Viscerossomatic index (VSI), hepatosomatic index (HSI), gonadosomatic index (GSI), gonad weight (GW), carcass yield $(\mathrm{CY})$ and carcass composition in dry matter $(\mathrm{DM})$, crude protein $(\mathrm{CP})$ and ether extract $(\mathrm{EE})$ of Nile tilapia fingerlings fed different levels of supplemental vitamin C

\begin{tabular}{lccccc}
\hline \multirow{2}{*}{ Item } & \multicolumn{5}{c}{ Treatment } \\
\cline { 2 - 5 } HSI & T1 & T2 & T3 & T4 & T5 \\
VSI & $11.28 \pm 4.07$ & $11.04 \pm 3.04$ & $12.04 \pm 3.04$ & $12.94 \pm 3.90$ & $13.22 \pm 3.90$ \\
GSI & $0.49 \pm 0.09^{\mathrm{c}}$ & $0.53 \pm 0.13^{\mathrm{b}}$ & $0.53 \pm 0.13^{\mathrm{b}}$ & $0.58 \pm 0.15^{\mathrm{b}}$ & $0.70 \pm 0.12^{\mathrm{a}}$ \\
GW & $0.11 \pm 0.07^{\mathrm{b}}$ & $0.10 \pm 0.05^{\mathrm{b}}$ & $0.17 \pm 0.22^{\mathrm{a}}$ & $0.17 \pm 0.22^{\mathrm{a}}$ & $0.17 \pm 0.22^{\mathrm{a}}$ \\
CY & $85.53 \pm 1.57$ & $86.10 \pm 1.36$ & $86.10 \pm 1.36$ & $86.66 \pm 2.34$ & $86.10 \pm 1.36$ \\
\hline & & Carcass composition in dry matter (DM) & & $26.86 \pm 1.70$ \\
\hline DM & $25.69 \pm 2.67$ & $26.13 \pm 1.45$ & $26.68 \pm 5.5$ & $26.68 \pm 5.5$ & $26.31 \pm 1.6$ \\
CP & $48.86 \pm 3.56$ & $48.87 \pm 2.35$ & $48.73 \pm 7.8$ & $48.73 \pm 7.8$ & $48.90 \pm 3.8$ \\
EE & $27.57 \pm 2.56$ & $27.40 \pm 4.5$ & $29.59 \pm 4.8$ & $29.59 \pm 4.8$ & $28.59 \pm 8.9$
\end{tabular}

Different letters in the row indicate significant differences $(\mathrm{p}<0.05)$ by Duncan's test; Mean \pm standard error. 


\section{CONCLUSION}

It could be concluded that T5 (spry added vitamin c with oil) was the best of growth performance and feed utilization of fingerlings Nile tilapia (Oreochrmis niloticus) under these experimental conditions.

\section{REFERENCES}

Abdelghany, A. (1996). Growth response of Nile tilapia Oreochromis niloticus to dietary L-ascorbic acid, Lascorbyl-2-sulfate, and L-ascorbyl-2polyphosphate. J. World Aquacult. Soc., 27: 449-445.

Ai, Q. H., K. S. Mai, B. P. Tan, W. Xu, W. B. Zhang and H. M. Ma (2006). Effects of dietary vitamin $\mathrm{C}$ on survival, growth, and immunity of large yellow croaker, Pseudosciaenacrocea. Aquaculture, 261: 327-336.

Ai, Q., K. Mai, C. Zhang, W. Xu, Q. Duan, B. Tan and Z. Liufu (2004). Effects of dietary Vitamin C on growth and immune response of Japanese seabass, Lateolabrax japonicus. The Key Laboratory of Mariculture, Ocean University of China, Qingdao 266003, P.R. China. Aquaculture, 62:1-12.

AOAC (2012). Official Methods of Analysis of AOAC International. Vol. I. Agriculture Chemicals; Contaminants, Drugs, 16thedn. AOAC International, Arlington, VA, USA.

Arai, S., T. Nose and Y. Hashimoto (1972). Qualitative requirements of young eels, Anguilla japonica, for water-soluble vitamins and their deficiency symptoms. B Freshwater Res Lab., 22: 69-83.

Chatterjee, I. B. (1973). Evolution and biosynthesis of ascorbic acid. Science, 182: 1271-1272.

Chou, R L., M. S. Su and H. Y. Chen (2001). Optimal dietary protein and lipid levels for juvenile cobia (Rachycentron canadum). Aquaculture, 193: 81-89

Duncan, N. B. (1955). Multiple Range and Multiple. FTest. Biometrics, 11: 1-24

Falcon, D. R., M. M. Barros, L. E. Pezzato and J. D. Valle (2007). Lipídeo e vitamina C emdietaspreparatórias de inverno para tilápias-do-Nilo. RevistaBrasileira de Zootecnia, 36(5): 1462-1472.

Fracalossi, D. M., M. E. Allen, L. K. Yuyama and O. T. Oftedal (2001). Ascorbic acid biosynthesis in Amazonian fishes. Aquaculture, 192: 321332.

Li, Y. and R. T. Lovell (1985). Elevated levels of dietary ascorbic acid increase immune response in channel catfish. J. Nutr., 115:123131.
Lin, M. F and S. Y. Shiau (2005). Dietary L-ascorbic acid affects growth, nonspecific immune responses and disease resistance in juvenile grouper, Epinephelus malabaricus. Aquaculture, 244: 215-221.

Martins, T. P. A. 1., P. F. V. Gomides, F. K. S. Navarro and R. D. N. Navarro (2016). Vitamin C supplementation on growth performance and gonadal development in Nile tilapia. Acta Scientiarum. Technology Maringá, v. 38, n. 4, p. 477-481.

Navarro, R. D., O. P. R. Filho, W. M. Ferreira and F. K. S. Pereira (2009). A importância das vitaminas E, C e Anareprodução de peixes: revisão de literatura. Revista Brasileira Reprodução Animal, 33(1): 20-25.

NRC (National Research Council) (1993). Nutrient Requirements of Fish. National Academies Press, Washington, DC.

Ross, L. G. (2000). Environmental physiology and energetics. In: Beveridge, M.C.M \& McAndrew, B.. J. (eds.) Tilapia: Biology and exploitation, pp.89-128.

SAS (2005). Statistical analysis System. User's guide: statistics. North Crolina: SAS Institute Cary.

Soliman, A. K., K. Jauncey and R. J. Roberts (1986). The effect of dietary ascorbic acid supplementation on hatchability, survival rate and fry performance in Oreochromis mossambicus (Peters). Aquaculture, 59(3-4): 197-208.

Stickney, R. R., R. B. McGeachin, D. H. Lewis, J. Marks, A. Riggs, R. F. Sis et al.. (1984). Response of Tilapia aurea to dietary vitamin C. Journal of the World Mariculture Society, 15: 179-185.

Stickney, R. R. (2000). Encyclopedia of aquaculture. John Wiley and Sons, Inc: New York, 960p.

Tolbert, B. M. (1979). Ascorbic acid metabolism and physiological function. Int. J. Vitam. Nutr. Res., 19: 127-142.

Stickney, R. R., R. B. McGeachin, D. H. Lewis and W. A. Wurts (2009). Response of Tilapia aurea to dietary vitamin C. Journal of the World Aquaculture Society, 15(1-4): 179-185.

Teshima, S. I., A. Kanazawa, S. Koshio and S. Itoh (1991). L-ascorbyl-2-phosphate-Mg as vitamin $\mathrm{C}$ source for the Japanese flounder (Paralichthy solivaceus ). In J. Kaushik and P. Lequet, (eds) Fish Nutrition in Practice, pp. 157- 166. Coll. Les Clloq., No. 61S., INRA, Paris, France.

Wilson, R. P. (1973). Absence of ascorbic acid synthesis in channel catfish, Ictalurus punctatus, and blue catfish, Ictalurus frucatus. Comp. Biochem. Phys., 46B: 635-638. 


\title{
تأثير طرق إضافة فيتامين سي على أداء النمو والاستفادة الغذائية لاصبعيات سمك البلطي النيلى المربى في هابات المئات
}

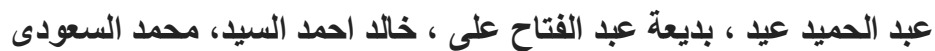

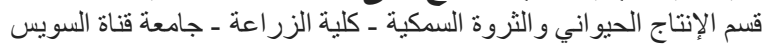

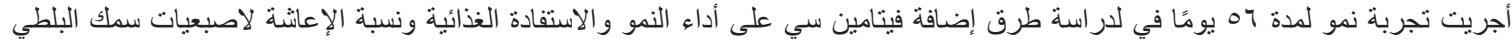

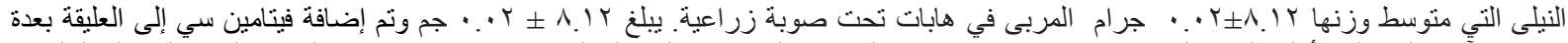

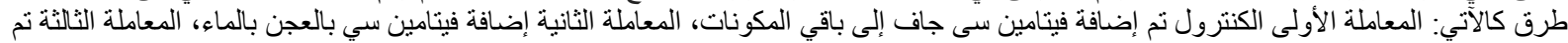

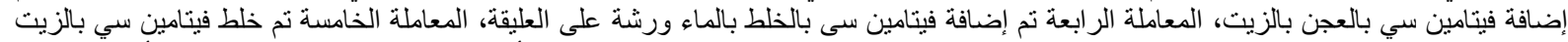

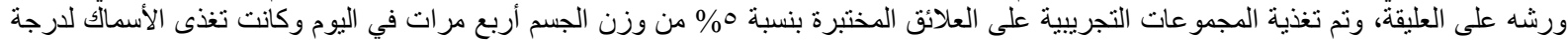

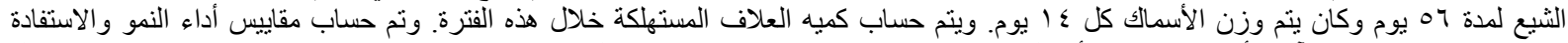

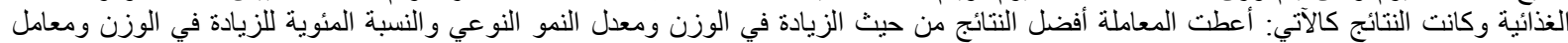

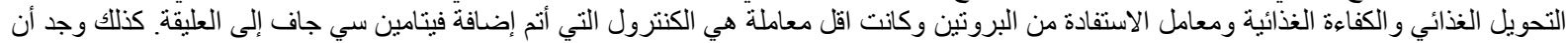

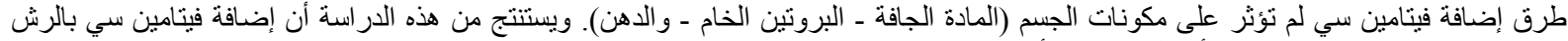

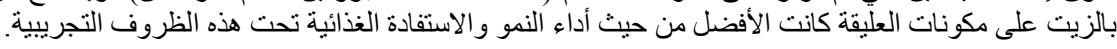
الكلمات اللالثة: سمك البلطي النيلىـ طرق إضافة فيتامين سي ـ أداء النمو ـ الاستفادة الغذائية ـ الإعانشة 